\title{
PERTUMBUHAN DAN HASIL JAGUNG HIBRIDA PULUT PUTIH DENGAN IDEOTIP TANAMAN TEGAK DI KABUPATEN BANJARNEGARA
}

\author{
Ulin Nuha $^{\text {a }}$, Dhoni Kusuma ${ }^{\text {b }}$, Rennanti Lunnadiyah Aprilia ${ }^{\text {c }}$, Aulia Rahmawati ${ }^{\text {d }}$ \\ a,b Mahasiswa Program Studi Agroteknologi, Ma'arif Nahdlatul Ulama, Kebumen, Indonesia \\ ${ }^{c, d}$ Dosen Program Studi Agroteknologi, Ma'arif Nahdlatul Ulama, Kebumen, Indonesia \\ ulinnuhaag11504@gmail.com ${ }^{\text {a }}, \underline{\text { ksmdoni19@gmail.com }}^{\text {b }}$, renantiaprilia@gmail.com ${ }^{\mathrm{c}}$, \\ awliarahmawati@gmail.com ${ }^{\mathrm{d}}$
}

\begin{abstract}
ABSTRAK
Jagung sebagai komoditas yang penggunaannya semakin luas saat ini yaitu sebagai bahan pangan langsung, pakan ternak dan bahan baku industri menjadikan komoditas ini sebagai komoditas ke-2 yang pengembangan dan perluasan tanamnya meningkat tajam di 10 tahun terakhir. Tujuan dari penelitian ini antara lain: (1) Mengetahui Hibrida Pulut yang memiliki karakter morfologi dan agronomi yang lebih baik daripada varietas pembanding Varietas Pulut URI 1 dan Pulut URI 2. (2) Mengetahui potensi hasil Hibrida Pulut dan varietas pembanding Varietas Pulut URI 1 dan Pulut URI 2 pada lokasi lahan persawahan banjarnegara. Penelitian ini dilakukan dengan menggunakan Rancangan Acak Kelompok (Randomized Completed Block Design), dengan 3 ulangan. Bila terdapat perbedaan nilai tengah varietas dalam uji $\mathrm{F}$, dilanjutkan dengan uji Least significance different (LSD) pada taraf nyata 5\%. Berdasarkan hasil penelitian diperoleh kesimpulan bahwa pemberian pupuk daun tidak memberikan pengaruh yang nyata terhadap variabel yang diamati meliputi tinggi tanaman, diameter batang, jumlah daun, luas daun total, bobot kering akar dan berat kering tajuk.
\end{abstract}

Kata Kunci : Jagung pulut, Pupuk, Produksi

\begin{abstract}
Corn as a commodity whose use is increasingly widespread today, namely as a direct food ingredient, animal feed and industrial raw material makes this commodity the 2nd commodity whose crop development and expansion has increased sharply in the last 10 years. The aims of this study were: (1) to find out the Pulut hybrids which have better morphological and agronomic characters than the comparison varieties, Pulut URI 1 and URI 2 Pulut varieties. Pulut URI 2 at the Banjarnegara rice field location. This research was conducted using a Randomized Completed Block Design, with 3 replications. If there is a difference in the mean value of the variety in the F test, it is continued with the Least significance different (LSD) test at the 5\% significance level. Based on the results of the study, it was concluded that the application of foliar fertilizers did not have a significant effect on the observed variables including plant height, stem diameter, number of leaves, total leaf area, root dry weight and shoot dry weight.
\end{abstract}



Keywords: Corn pulut, Fertilizer, Production

\section{PENDAHULUAN}

Jagung sebagai komoditas yang penggunaannya semakin luas saat ini yaitu sebagai bahan pangan langsung, pakan ternak dan bahan baku industri menjadikan komoditas ini sebagai komoditas ke-2 yang pengembangan dan perluasan tanamnya meningkat tajam di 10 tahun terakhir. Masuk kedalam 3 komoditas penting jagung dalam program PAJALE (PADI, JAGUNG dan KEDELAI) pemerintah, produksi jagung diharapkan mampu untuk memenuhi kebutuhan masyarakat Indonesia. Target produksi yang meningkat tentu harus diikuti peningkatan sumberdaya yang proporsional dengan tuntutan yang diberikan.

Berbagai upaya yang dilakukan untuk meningkatkan produksi jagung nasional diantaranya melalui perluasan areal tanam (ekstensifikasi) terutama di luar Jawa dan peningkatan produktivitas per satuan luas (intensifikasi). Volume produksi berdasarkan data perkiraan dari Kementan selama lima tahun terakhir, produksi jagung meningkat rata-rata 12,49 persen per tahun dengan penambahan luas lahan panen 11 persen dan produktivitas naik 1,42 persen. Dalam melaksanakan program intensifikasi, salah satu komponen adalah menggunakan varietas unggul. Penggunaan jagung hibrida dalam meningkatkan hasil per satuan luas, bermuara pada peningkatan produksi jagung secara nasional.

Jagung pulut atau jagung ketan termasuk jenis jagung khusus yang makin populer dan banyak dibutuhkan konsumen dan industri. Jagung pulut mempunyai citarasa yang enak, lebih gurih, lebih pulen dan lembut. Rasa gurih muncul karena kandungan amilopektin yang terkandung dalam jagung pulut sangat tinggi, mencapai 90\%. Struktur pati dari jagung pulut juga termasuk spesifik sehingga cocok pula untuk kebutuhan industri, selain untuk kebutuhan pangan. Tingginya persentase kandungan fraksi tepung pada endosperma biji memberikan kontribusi terhadap kandungan pati yang tinggi pada biji, sehingga cocok untuk industri etanol (Kopyra, 2012). Pamor jagung pulut tidak luntur ditelan zaman. Kreasi baru makanan olahan berbasis jagung pulut mermunculan termasuk beras jagung instan, bubur jagung instan dan lainlain.

Terlepas dari kelebihan yang dimiliki, jagung pulut juga mempunyai kelemahan, salah satunya tingkat produktivitasnya yang masih rendah, antara 2-2, 5 t/ha. Upaya untuk meningkatkan produktivitas jagung pulut, salah satunya dengan persilangan dengan plasma nutfah lokal yang mempunyai potensi hasil yang tinggi berupa jagung pulut hibrida. Harapan dari perakitan jagung pulut hibrida adalah menghasilkan varietas jagung pulut baru dengan produktivitas mencapai 6 t/ha atau lebih (tiga-empat kali lebih tinggi dari jagung pulut lokal). Selain itu kandungan amilopektin juga tinggi sampai 90\% sehingga memberi rasa gurih. Jagung hibrida pulut yang baru dapat digunakan untuk memenuhi permintaan industri olahan berbasis jagung seperti jagung marning serta dapat diolah menjadi bahan makanan alternatif lainnya guna mendukung swasembada pangan nasional. Penelitian mengenai jagung pulut hibrida diarahkan menuju peningkatan produktifitas yang tinggi.

\section{METODOLOGI PENELITIAN}

Penelitian dilaksanakan pada bulan Juli-Oktober tahun 2020 di lahan sawah desa Gumiwang, kecamatan Purwanegara, kabupaten Banjarnegara, Jawa Tengah dengan ketinggian tempat $200 \mathrm{~m}$ dpl serta jenis tanah Latosol. Materi genetik yang digunakan dalam penelitian ini 
Program Studi Agroteknologi, Universitas Ma'arif Nahdlatul Ulama Kebumen terdiri atas 6 genotipe uji yaitu: Hibrida Pulut 1, Hibrida Pulut 2, Hibrida Pulut 3, Hibrida Pulut 4, Hibrida Pulut 5 dan Hibrida Pulut 6 serta 2 varietas pembanding yaitu: Pulut URI 1 dan Pulut URI 2.

Penelitian ini dilakukan dengan menggunakan Rancangan Acak Kelompok (Randomized Completed Block Design), dengan 3 ulangan. Bila terdapat perbedaan nilai tengah varietas dalam uji F, dilanjutkan dengan uji Least Significance Different (LSD) pada taraf nyata $5 \%$.

\section{HASIL DAN PEMBAHASAN}

Pengolahan tanah dilakukan dengan olah tanah sempurna, kemudian dibuat plot berukuran 3 meter x 5 meter dan lubang tanam dengan jarak 70 x $20 \mathrm{~cm}$. Benih ditanam 2 biji per lubang. Saat tanaman berumur 10 hari setelah tanam (hst), dilakukan penjarangan menjadi 1 tanaman per rumpun. Pemupukan. Dosis dan waktu pemupukan mengikuti kebiasaan petani setempat, namun bagi petani yang belum terbiasa menanam jagung dengan pengelolaan yang optimal, dapat mengikuti dosis dan waktu pemupukan sebagai berikut:Pemupukan pertama, diberikan pupuk NPKS (15:15:15:15) pada umur 7 - 10 hari setelah tanam (hst), dosis $350 \mathrm{~kg} /$ ha. Pemupukan kedua, diberikan pada saat tanaman berumur $30-35$ hst dengan dosis $250 \mathrm{~kg}$ Urea/ha.

Penyiangan dilakukan dengan membersihkan gulma yang berada di sekitar tanaman sedangkan pembumbunan dilakukan dengan meninggikan guludan dan penggemburan tanah untuk menciptakan aerasi tanah yang lebih baik. Penyiangan pertama dilakukan sebelum pemupukan kedua, sedangkan pembumbunan dilakukan setelah pemupukan kedua. Pengendalian hama dilakukan untuk menanggulangi serangan hama yang dapat mengganggu pertanaman jagung seperti : hama ulat bibit, belalang, dan ulat peggerek batang dan tongkol. Pengendalian penyakit bulai dilakukan dengan memberikan perlakuan fungisida methalaxil pada benih sebelum ditanam. Pengendalian hama dan penyakit dilakukan dengan mengunakan pestisida sesuai dengan dosis anjuran.

Panen dilakukan pada saat tanaman sudah masak fisiologis yang ditandai dengan munculnya lapisan hitam pada sisi belakang biji. Panen dilakukan secara manual pada dua baris tengah tanaman per nomor kemudian diprosesing untuk pengamatan komponen hasil dan hasil. Bagian yang dipanen untuk pengamatan hasil berupa tongkol jagung. Letak tongkol tanaman jagung adalah pada sekitar pertengahan batang dan berada pada salah satu ketiak daun. Berikut hasil pengamatan lingkungan dan variabel fisiologi pada penelitian.

Tabel 1. Hasil Pengamatan Beberapa Variabel

\begin{tabular}{|c|c|c|c|c|c|c|c|c|c|c|c|c|c|}
\hline \multirow{3}{*}{ PLOT } & \multirow{3}{*}{ REF } & \multirow{3}{*}{ ACAK } & \multirow{3}{*}{ GENOTIP } & \multirow{3}{*}{$\begin{array}{c}\text { Jum } \\
\text { Tan } \\
\text { Tum }\end{array}$} & \multirow{2}{*}{\multicolumn{2}{|c|}{$\begin{array}{c}\text { umur } \\
\text { bunga } 50 \%\end{array}$}} & \multicolumn{3}{|c|}{ Scor } & \multicolumn{2}{|c|}{ Jumlah } & \multirow{3}{*}{$\begin{array}{l}\text { Bbt tk1 } \\
\text { Kupas } \\
\text { Basah }\end{array}$} & \multirow{3}{*}{ KA } \\
\hline & & & & & & & \multirow{2}{*}{\begin{tabular}{|c|} 
Plant \\
aspect
\end{tabular}} & \multirow{2}{*}{$\begin{array}{l}\text { Housk } \\
\text { cover }\end{array}$} & \multirow{2}{*}{\begin{tabular}{|c|} 
Ear \\
Aspect
\end{tabular}} & \multirow{2}{*}{\begin{tabular}{|c|} 
Tan \\
Panen
\end{tabular}} & \multirow{2}{*}{$\begin{array}{c}\text { tkl } \\
\text { panen }\end{array}$} & & \\
\hline & & & & & Tas & Silk & & & & & & & \\
\hline 1 & 1 & 7 & Pulu & 84 & 47 & 49 & 3 & 1,5 & 3 & 50 & 50 & 8240 & 32 \\
\hline 2 & 4 & - & & 90 & 47 & & & 2 & 3 & 50 & & & 30,2 \\
\hline 3 & 1 & 5 & 6 & 90 & 47 & 48 & 2,5 & 1,5 & 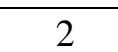 & 50 & 50 & 55 & 28,4 \\
\hline 4 & 1 & 2 & 3 & 83 & 49 & 52 & 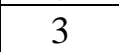 & 0 & 3 & 50 & 50 & 95 & 29,3 \\
\hline 5 & 1 & 0 & & 85 & 51 & & 3 & 1 & 3 & 50 & 5( & & 31,1 \\
\hline 6 & 1 & 1 & $\mathrm{P} 1 \times \mathrm{P} 2$ & 79 & 53 & 54 & 3 & 1,5 & 2,5 & 50 & 50 & 7575 & 30,1 \\
\hline
\end{tabular}


Program Studi Agroteknologi, Universitas Ma'arif Nahdlatul Ulama Kebumen

\begin{tabular}{|c|c|c|c|c|c|c|c|c|c|c|c|c|c|}
\hline 7 & 1 & 3 & P 3 x P 4 & 97 & 52 & 55 & 2,5 & 2,5 & 2,5 & 50 & 50 & 6445 & 28,5 \\
\hline 8 & 1 & 4 & P 3 x P & 93 & 52 & 54 & 2,5 & 2,5 & 2,5 & 50 & 50 & 6680 & 27,7 \\
\hline 9 & 2 & 7 & Pulut Uri 1 & 96 & 47 & 50 & 3 & 1,5 & 3 & 50 & 50 & 5895 & 29,3 \\
\hline 10 & 2 & 2 & P 2 x P 3 & 85 & 50 & 52 & 2,5 & 2,5 & 3 & 50 & 50 & 8160 & 27,7 \\
\hline 11 & 2 & 1 & P 1 x P 2 & 85 & 52 & 54 & 3 & 2,5 & 3 & 50 & 50 & 8175 & 29,3 \\
\hline 12 & 2 & 3 & P 3 x P 4 & 72 & 53 & 55 & 2,5 & 2,5 & 2,5 & 50 & 50 & 7415 & 26,8 \\
\hline 13 & 2 & 5 & P 4 x P 6 & 78 & 49 & 51 & 2,5 & 3 & 2,5 & 50 & 50 & 8388 & 28,1 \\
\hline 14 & 2 & 6 & P 5 x P 6 & 95 & 49 & 52 & 3 & 3 & 3 & 50 & 50 & 6150 & 29,8 \\
\hline 15 & 2 & 8 & Pulut Uri 2 & 95 & 47 & 52 & 3 & 2 & 3 & 50 & 50 & 6315 & 29,7 \\
\hline 16 & 2 & 4 & P 3 x P 5 & 93 & 50 & 52 & 3 & 2,5 & 3 & 50 & 50 & 7645 & 30,3 \\
\hline 17 & 3 & 1 & P 1 × P 2 & 90 & 49 & 51 & 3 & 2,5 & 3 & 50 & 50 & 4705 & 30,4 \\
\hline 18 & 3 & 4 & P 3 x P 5 & 89 & 49 & 51 & 2,5 & 2,5 & 3 & 50 & 50 & 8110 & 34,5 \\
\hline 19 & 3 & 5 & P 4 x P 6 & 92 & 47 & 50 & 3 & 3 & 3 & 50 & 50 & 7625 & 28,1 \\
\hline 20 & 3 & 8 & Pulut Uri 2 & 94 & 49 & 51 & 3 & 2 & 3 & 50 & 50 & 6725 & 29 \\
\hline 21 & 3 & 6 & P 5 x P 6 & 91 & 47 & 49 & 3 & 2 & 2,5 & 50 & 50 & 6215 & 29,9 \\
\hline 22 & 3 & 7 & Pulut Uri 1 & 85 & 49 & 51 & 3 & 2 & 3 & 50 & 50 & 6025 & 29,7 \\
\hline 23 & 3 & 2 & P 2 x P 3 & 92 & 48 & 51 & 2,5 & 2,5 & 3 & 50 & 50 & 6610 & 27,5 \\
\hline 24 & 3 & 3 & P 3 × P 4 & 96 & 50 & 52 & 2,5 & 3 & 3 & 50 & 50 & 7880 & 30,3 \\
\hline 25 & 4 & 1 & P 1 x P 2 & 85 & 49 & 51 & 3 & 3 & 3 & 50 & 50 & 7130 & 29,1 \\
\hline 26 & 4 & 7 & Pulut Uri 1 & 92 & 47 & 49 & 3 & 2,5 & 3 & 50 & 50 & 6860 & 28 \\
\hline 27 & 4 & 5 & P 4 x P 6 & 90 & 50 & 52 & 2,5 & 2,5 & 2,5 & 50 & 50 & 7140 & 29,8 \\
\hline 28 & 4 & 2 & P 2 x P 3 & 78 & 51 & 53 & 3 & 2,5 & 3 & 50 & 50 & 7070 & 30,1 \\
\hline 29 & 4 & 8 & Pulut Uri 2 & 89 & 47 & 49 & 2,5 & 2 & 3 & 50 & 50 & 6580 & 29,4 \\
\hline 30 & 4 & 6 & P 5 x P 6 & 96 & 48 & 50 & 3 & 2 & 3 & 50 & 50 & 6305 & 29,3 \\
\hline 31 & 4 & 3 & P 3 x P 4 & 94 & 49 & 51 & 2,5 & 2 & 3 & 50 & 50 & 7575 & 30,6 \\
\hline 32 & 4 & 4 & P 3 x P 5 & 88 & 48 & 51 & 2,5 & 2,5 & 2,5 & 50 & 50 & 7405 & 32,7 \\
\hline
\end{tabular}

Komponen umur berbunga yang diamati, yakni umur berbunga jantan dan umur berbunga betina dari tanaman jagung hibrida pulut putih yang menunjukkan bahwa antara keduanya tidak berbeda nyata. Pada saat pembungaan (bunga jantan) tanaman jagung telah mengabsorbsi sebanyak $50 \%$ Nitrogen dari seluruh kebutuhannya. Dengan demikian karena ada ketersediaan unsur hara Nitrogen, maka penambahan panjang, diameter dan berat biji dapat berlang- sung lebih banyak (Erungan et al., 2012). Silk atau rambut jagung merupakan pemanjangan dari saluran stylar ovary yang matang pada tongkol. Zubachtirodin et al. (2011) menyatakan bahwa tanaman jagung termasuk tanaman berumah satu, yaitu bunga jantan dan bunga betina terdapat dalam satu tanaman tetapi letaknya terpisah. Bunga jantan tanaman jagung biasanya lebih dulu masak dari bunga betina, yaitu 1-3 hari sebelum bunga betina masak. Alhussein dan Idris (2017) juga mendapatkan bobot kupasan basah memiliki pengaruh langsung yang rendah terhadap hasil biji. Karakter bobot kupasan basah dapat dipakai sebagai indikator seleksi untuk hasil tinggi (Priyanto et al., 2018).

Dari hasil penelitian menunjukkan variable tinggi tanaman tidak berbeda nyata. Hal tersebut dikarenakan semua perlakuan tidak menunjukkan perbedaan secara data statistic. Namun demikian jika dilihat dari hasil Plut URI II mempunyai tinggi tanaman yang paling tinggi. Dari hasil penelitian menunjukkan variable tinggi letak tongkol tidak berbeda nyata. Hal tersebut dikarenakan semua perlakuan tidak menunjukkan perbedaan secara data statistik. Namun demikian jika dilihat dari hasil Plut URI II mempunyai tinggi letak tongkol yang paling 
Program Studi Agroteknologi, Universitas Ma'arif Nahdlatul Ulama Kebumen tinggi. Menurut Riadi et al., (2015), semakin tinggi tanaman jagung maka semakin tinggi pula tinggi letak tongkolnya dan letak tongkol berada pada sekitar pertengahan dari tinggi batang.

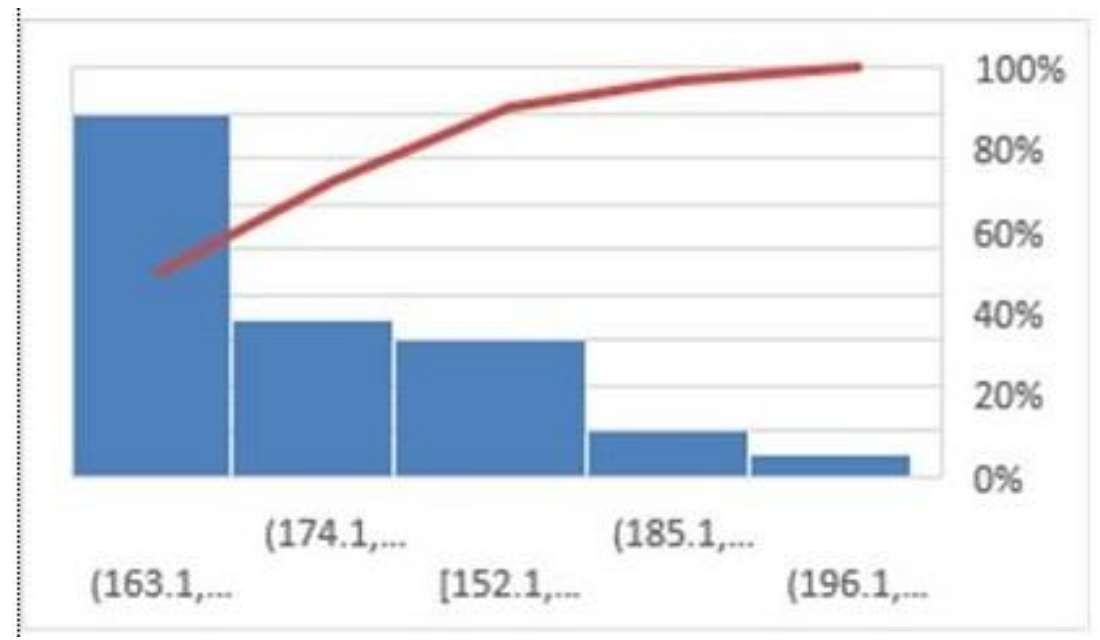

Gambar 1 Tinggi tanaman

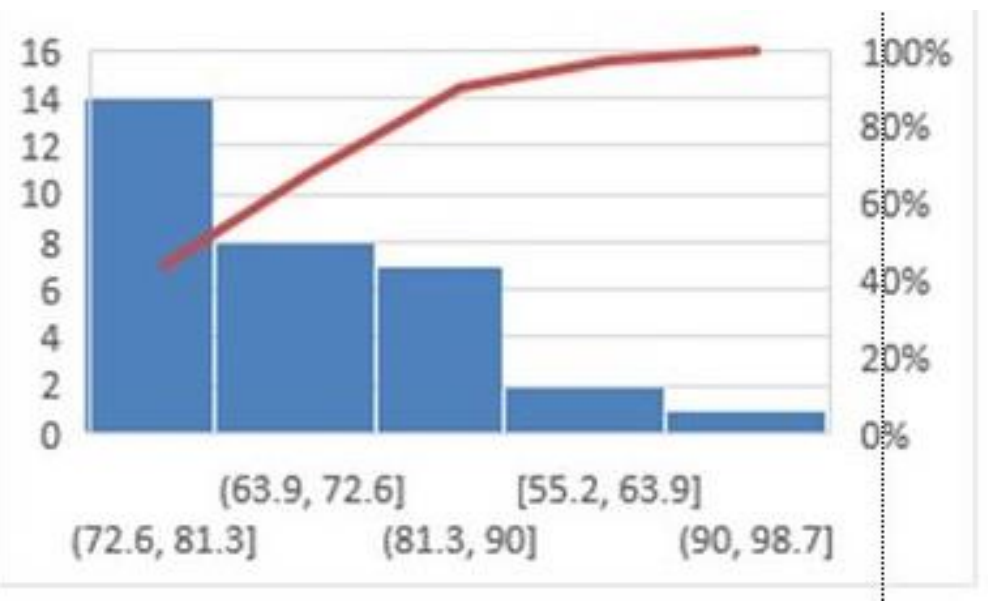

Gambar 2 Tinggi letak tongkol

Untuk hasil dari jagung meliputi Panjang tongkol, diameter tongkol, jumlah baris, jumlah biji dalam baris masing-masing juga tidak berbeda nyata. Hal tersebut dikarenakan secara fisiologi setiap perlakuan tidak berpengaruh nyata terhadap variable tersebut. Panjang tongkol berbiji menggambarkan panjangnya tongkol yang ada bijinya. Maka diperlukan penelitian lanjutan untuk mendapatkan dosis pupuk terbaik dari PLUT URI 1 dan 2. Berikut adalah diagaram batang dari hasil tanaman namun demikian semua variable baik pada variabel pertumbuhan maupun variable hasil PLUT 2 menunjukkan hasil yang paling baik.

Jumlah tanaman yang dipanen dipengaruhi oleh jumlah tanaman tumbuh, serangan organisme pengganggu tanaman (OPT), kerebahan tanaman (Priyanto et al., 2017). Jika kerebahan terjadi sebelum penyerbukan akan berpengaruh pada pengisian tongkol dan pada keadaan yang parah bisa mengakibatkan tanaman tidak menghasilkan tongkol. Sedangkan jika kerebahan terjadi pada saat pengisian biji akan berakibat pada berkurangnya jumlah biji per tongkol, bobot biji dan biji tidak terisi sempurna. Berdasarkan Tabel 1, jumlah tanaman yang dipanen setara dengan jumlah tongkol panen, berarti satu tanaman memiliki satu tongkol jagung. Fungsi tongkol jagung adalah sebagai tempat menyimpan persediaan makanan yang 
Program Studi Agroteknologi, Universitas Ma'arif Nahdlatul Ulama Kebumen dihasilkan dari proses fotosintesis pada daun, yaitu berupa protein, minyak, zat pati, dan hasil lain, sebagai lembaga muda (calon biji). Biji jagung terletak pada janggel yang tersusun memanjang dan menempel erat.

Pada saat penelitian $\mathrm{pH}$ tanah normal, agrolimat normal, suhu curah hujan juga normal tidak terjadi ledakkan penyakit pada tanaman, walaupun ada beberapa hama dan penyakit yang menyerang seperti hawar daun dan karat yang ada di scor 2 dan 3. Hal ini didukung oleh Effendi (2009), bahwa strategi pengelolaan risiko untuk mengendalikan gulma, hama, dan penyakit tanaman dapat mencegah terjadinya ledakan penyakit. Strategi pengelolaan risiko dalam penelitian ini yaitu penanaman yang dilakukan pada kondisi lingkungan normal untuk mendukung pertumbuhan tanaman jagung hibrida pulut putih. Penggunaan varietas tahan juga merupakan strategi pengelolaan risiko, dimana varietas tahan tersebut banyak terdapat pada tanaman hibrida. Sesuai dengan objek pada penelitian ini yaitu tanaman jagung hibrida pulut putih.

\section{KESIMPULAN}

Berdasarkan hasil penelitian diperoleh kesimpulan bahwa pemberian pupuk tidak memberikan pengaruh yang nyata terhadap variabel yang diamati meliputi tinggi tanaman, tinggi letak tongkol, Panjang tongkol, diameter tongkol, jumlah baris, jumlah biji dalam baris masing-masing.

\section{DAFTAR PUSTAKA}

Alhussein, M.B. \& Idris, A.E. (2017). Correlation and path analysis of grain yield components in some maize (Zea mays L.) genotypes. International $J$ of Advanced Research Publications, 1(1), 79-82

Effendi, B.S. (2009). Strategi pengendalian hama terpadu tanaman padi dalam perspektif praktek pertanian yang baik (good agricultural practices). Pengembangan Inovasi Pertanian, 2(1), 65-78

Erungan, R.H., Runtunuwu, D.S. \& Rogi, J.E.X. (2012). Produksi jagung manado kuning pada jarak tanam dan dosis pupuk nitrogen berbeda. Eugenia, 18(3), 230-236

Kopyra, A.K., Szmigiel, A., Zajac, T. \& Kidacka, A. (2012). Some aspects of cultivation and utilization of waxy maize (Zea mays L. ssp ceraiona). Acta Agrobotanica, 65(3), 3-12

Priyanto, S.B., Azrai, M. \& Makkulawu, A.T. (2017). Parameter genetik dan korelasi karakter komponen hasil jagung hibrida. Buletin Penelitian Tanaman Sereila, 1(2), 9-15

Priyanto, S.B., Azrai, M. \& Syakir, M. (2018). Analisis ragam genetik, heritabilitas, dan sidik lintas karakter agronomik jagung hibrida silang tunggal. Informatika Pertanian, 27(1), $1-8$

Riadi, M., Jaya, A.M., Makkulawu, A.T. \& Said, M.H. (2015). Pertumbuhan dan produksi jagung hibrida hasil persilangan antara jagung manis komersial dengan jagung pulut. $J$ Agrotan, 1(1), 88-99 
AGRONU: JURNAL AGROTEKNOLOGI

Pertumbuhan Dan Hasil Jagung Hibrida Pulut Putih dengan Ideotip Tanaman Tegak Di Kabupaten Banjarnegara Vol. 01 No.01 2022 E-ISSN: 0000-0000

Program Studi Agroteknologi, Universitas Ma'arif Nahdlatul Ulama Kebumen

Zubachtirodin, Sugiharto, B., Mulyono \& Herman, D. (2011). Teknologi budidaya jagung.

Kementerian Pertanian, Direktorat Jenderal Tanaman Pangan, Direktorat Budidaya Serealia, Jakarta 